\title{
Konya Organize Sanayi Bölgesi'nde Ymm Hizmeti Alan Firmaların Yönetim Muhasebesi Uygulama Gücü ve Ymm’lerin Rolü
}

\author{
Fehmi KARASİOĞLU* \\ İbrahim Emre GÖKTÜRK** (D) \\ Mustafa İYİBİLDİREN*** (D)
}

ÖZ

$\mathrm{Bu}$ çalıșma, işletmelerin gerçekleștirdikleri faaliyetler ve karar alma süreçlerinde, yönetim muhasebesinden ne derecede yararlandıklarını ve bu faaliyetlerin gerçekleştirilme sürecinde yönetim muhasebesinin kullanımına yönelik YMM' lerden aldıkları destekleri tespit etmeyi amaçlamaktadır. Bu doğrultuda literatür yazınından faydalanılarak işletme yönetimlerinin karar alma süreçlerin de etkinliğini sağlayacak yönetim muhasebesinin görevleri tespit edilmiştir. Bu görevler doğrultusunda oluşturulan ölçekler aracllığı ile işletmelerin yönetim muhasebesi faaliyetlerini uygulama güçleri ve bu faaliyetler de YMM'lerden aldıkları destekler analizlere tabii tutulmuștur.

Çalışma, Konya Organize Sanayii Bölgesi' nde YMM' ler ile çalısan işletmelerle gerçekleştirilmiştir. Yapılan analizler sonucunda, yönetim muhasebesi uygulamalarında YMM' lerden yeterli desteği alabilen işletmelerin oranı \%17,5, yeterli desteği alamayan işletmelerin oranı ise $\% 82,5$ olarak bulunmuştur.

İşletmelerin yönetim muhasebesi ile ilişkili olarak gerçekleştirdikleri, finansal kontrol ve işletme performans ölçümleri en yüksek uygulama gücüne sahip faaliyetlerdir. Bu faaliyetlerin gerçekleştirilmesi sürecinde YMM' lerden de yeterli desteği aldıkları görülmektedir. Buna karşın YMM' lerden yeterli desteği alamadıkları; üretim, müşteri ve tedarikçi yönetimi uygulamalarına yönelik gerçekleştirilen faaliyetler de ise uygulama güçlerinin de düşük olduğu tespit edilmiştir. Bu durum YMM’ lerin yönetim muhasebesi uygulamalarında işletmelere sağlayacağı desteklerin etkinliğini göstermesi açısından önemlidir.

Anahtar Kelimeler: Muhasebe, Yönetim Muhasebesi, Yeminli Mali Müşavir (YMM)

\section{Management Accounting Practice Strength of Companies Purchasing Certified Public Accountant (Cpa) Services in Konya Organized Industrial Zone and the Act of Cpas}

\begin{abstract}
This study aims to determine the extent to which businesses benefit from management accounting in their activities and decision-making processes and the support they receive from CPAs for the use of management accounting in the realization of these activities. In this direction, the tasks of management accounting that will ensure the efficiency of business management in decision-making processes have been determined by making use of the literature. Through the scales created in line with these tasks, the strengths of the enterprises in the implementation of management accounting activities and the supports they received from CPAs in these activities were analyzed.

The study was carried out with enterprises working with CPAs in Konya Organized Industrial Zone. As a result of the analysis, the rate of enterprises that can receive sufficient support from CPAs in management accounting practices was found to be $17.5 \%$, and the rate of enterprises that could not receive sufficient support was found to be $82.5 \%$.

Financial control and business performance measurements carried out by businesses concerning management accounting are the activities with the highest application power. In the process of realizing these activities, it is seen that they receive sufficient support from CPAs. On the other hand, they could not get enough support from CPAs; In the activities carried out for production, customer, and supplier management practices, it has been determined that their implementation strengths is also low. This situation is important in terms of showing the effectiveness of the support that CPAs will provide to businesses in management accounting applications.
\end{abstract}

Keywords: Accounting, Management Accounting, Certified Public Accountant (CPA)

\footnotetext{
* Prof. Dr., Selçuk Üniversitesi, fehmibey@gmail.com

** Dr. Öğr. Üyesi, Necmettin Erbakan Üniversitesi, iegokturk@gmail.com

*** Dr. Öğr. Üyesi, Necmettin Erbakan Üniversitesi, iyibildiren@yahoo.com

Makalenin Gönderim Tarihi: 26.11.2020 , Makalenin Kabul Tarihi: 20.01.2021
} 


\section{Giriş}

Yönetim; insan ve diğer kaynakları mümkün olan en iyi șekilde birleștirerek, örgütsel amaçlara etkin ve verimli ulaşma sürecidir. Diğer bir ifade ile yönetim; iş gücü, sermaye, teknik donanım vb. gibi örgütsel kaynakların, örgütsel amaçlan gerçekleştirmek üzere etkin bir şekilde koordine edilmesidir (Güçlü, 2003, s. 63). Bu açıdan yönetim; örgütlerin amaçlanına etkin ve verimli ulaşabilmeleri bakımından zorunlu bir işlevdir.

Muhasebe ise şu şekilde tanımlanmaktadır: İşletmelerde meydana gelen mali nitelikli ve para ile ifade edilebilen olay ve işlemleri belirli bir düzen içerisinde kaydeden, sınıflandıran, özetleyen, analiz eden ve yorumlayan bir bilim dalıdır (Karasioğlu, 2019, s. 4).

$\mathrm{Bu}$ iki tanımdan hareketle yönetim muhasebesinin amac1; işletme yöneticilerinin sağlıklı karar alabilmeleri için ihtiyaç duydukları bilgilerin sağlanmasıdır. Bu sayede yönetim muhasebesi, işletmenin vizyoner bir bakış açısıyla yönetim kararlarının alınmasını sağlayacak muhasebe kombinasyonunu oluşturan bir fonksiyonu üstelenir (Büyükmirza, 2003, s. 29).

Yönetim muhasebecisini ise bu amaç doğrultusunda; işletme yönetiminde kaynakları işletme amaçlarına yönlendiren kişi olarak tanımlamak mümkündür. Yönetim muhasebesinin ve muhasebecisinin ana odağ1 her zaman planlama, kontrol ve karar alma için gerekli bilgileri sağlayarak organizasyonun performansını ve karlılı̆̆ını artırmaya yöneliktir (Sunarni, 2013, s. 616).

Yönetim muhasebesi kavramını geçmişten günümüze dönemler halinde inceleyerek, hangi amaca yönelik bir faaliyet olduğunu anlamak mümkün olacaktır.

Yönetim muhasebesinin günümüz uygulamalarnna ulaşıncaya kadar dört önemli evreden geçtiğini görüyoruz. Kader ve Luther bu evreleri şu şekilde sıralamaktadır: Birinci evre, 1950 öncesini ifade etmektedir ve maliyet tanımlamalanı ve finansal kontrol çalışmalarını içermektedir, ikinci evre 1950-1960’lı y1llarda yönetim planlaması ve kontrolünü kapsarken, üçüncü evre 1970’li yıllarda dünyadaki resesyon ve izleyen petrol krizlerinin ardından 1980'li yllardaki küresel rekabetin artışı ve bilgisayar kullanımının artması ile birlikte muhasebe alanında nitelikli verilere sahip olma dönemi olarak karșımıza çıkmaktadır. Dördüncü ve içinde bulunduğumuz evre ise 1995 'leden sonra değer oluşturma, teknolojik gelişmeler ve organizasyonel inovasyonlardan oluşan dönemdir (Magdy \& Luther, 2008, s. 4-5). Teknolojinin getirdiği dijital dönüşümün uygulandığ sürecinde daha etkin kullanmak için bulut yazılımlar, büyük veri vb. gibi teknolojilerden etkin olarak yaralanabilmektedir. Son evre ise "Toplum 5.0" veya "Süper ak1llı toplum" olarak da ifade edilmektedir. Bu evre ilk olarak Japonya'da tanımlanan ve gelecekte insanların, robotların ve yapay zekanın güç birliği yaptığı bir toplumu temsil etmektedir. Bu evre, "robot" kelimesinin tanımını değiştirerek, yalnızca tekrar eden görevleri yerine getirebilen programlanabilir bir makine olmaktan daha çok bazı senaryolar için insanla işbirliği içinde çalşsan işbirlikçi robotlara (Cobot) dönüştürmektedir (Nahavandi, 2019, s.3). Muhasebe, insan ve yapay zeka ile donatılmıs cobotların işbirliği ile işletmelerde karar verme ve denetim sürecinde daha etkin ve verimli bir șekilde kullanılabilecektir.

Finansal muhasebe ve yönetim muhasebesinin kullanımı yönetim düzeyine bağlı olarak gerçekleşmektedir. Çünkü her yönetim düzeyi farklı becerileri gerektirmektedir. Finansal muhasebe ve yönetim muhasebesi arasındaki farklar Tablo 1' de verilmiştir.

Tablo 1. Finansal Muhasebe ve Yönetim Muhasebesi Arasindaki Farklar

\begin{tabular}{|c|c|}
\hline Finansal Muhasebe & Yönetim Muhasebesi \\
\hline İç kullanıcılar yanında dış kullanıcılar için de bilgi sağlama & İç kullanıcılara yönelik bilgi sağlama \\
\hline Yasal zorunluluk vardır. & Yasal zorunluluk yoktur. \\
\hline Genel kabul görmüş muhasebe ilkelerine bağlıdır. & Genel kabul görmüş muhasebe ilkelerine bağlı değildir. \\
\hline Doğru ve zamanında bilgi vermek zorundadır. & Bilginin ilișkili olması ve esnekliği üzerinde durulur. \\
\hline $\begin{array}{l}\text { Geçmiş veriler ve belgelere dayanan mali olaylarla ilgili işlemlerle } \\
\text { ilgilenir }\end{array}$ & $\begin{array}{c}\text { Geçmiş veriler yanında gelecekle ilgili veri ve belgelerle } \\
\text { ilgilenir. }\end{array}$ \\
\hline İssletmeyi bir bütün olarak görür. & İşletmenin bütünü yanında bölümlerine de odaklanır. \\
\hline $\begin{array}{c}\text { Para birimi ile ölçülebilen veriler asıldır. Sayısal bilgiler parasal } \\
\text { hesaplamaların gerekliliği durumunda kullanılır. }\end{array}$ & $\begin{array}{l}\text { Parasal veriler yanında sayısal bilgilerin toplanması, } \\
\text { ișlenmesi ve raporlanması gerçekleștirilir. }\end{array}$ \\
\hline Sonuç üretir (kar/zarar) & Sonuçlar için bir araçtır. \\
\hline
\end{tabular}

Kaynak: Elmacı 2007,17; Ertaş 2015;7 
$\mathrm{Bu}$ farklarla birlikte finansal muhasebe ile yönetim muhasebesi, muhasebe bilgi sistemini kullanmalar1 ve bilgi alışverişlerinden dolayı birbirinden bağımsız olarak da düşünülmemelidir. Sonuçta her ikisi de organizasyonlarda muhasebe sisteminin etkin ve verimli kullanılması için çaba sarfetmektedir. Devie, Tarigan ve Kunto (2008) örgüt içinde üç tip yönetim muhasebecisinin varlığından söz etmektedirler. Buna göre birinci düzey yöneticilerde yönetim muhasebecisi, zamanını işlem kaydı ve mali tablo hazırlama ile değerlendirmektedir. İkinci düzey yönetim seviyesinde yönetim muhasebecisi, üst düzey yönetim için stratejik katkı sağlayacak konular üzerinde durmaktadır. Üçüncü düzey yönetim seviyesinde ise yönetim muhasebecisi, veriler sşığında liderlik etme, motive etme ve iletişim kurma görevini üstlenmektedir.

Yönetim muhasebesinin gücünü ortaya koymak örgüt içerisinde yönetim muhasebesinin önemini algılamış ve bu konuda profesyonel bilgi ve tecrübeye sahip bireylerin varllğı ile mümkün olabilecektir. Fakat özellikle kurumsal ve stratejik yapılanmayı gerçekleştirmeyi sağlayamamış sektörlerde profesyonel yöneticilere sahip olmak her zaman mümkün olamamaktadır. Bu durumda ileri muhasebe sistemleri konusunda ekonomik sistem içerisinde yer alan aktörlerden faydalanmak gerekmektedir. Yönetim muhasebesi konusunda bilgi birikimine sahip en kalifiye aktörler yeminli mali müşavirlerdir.

Modern işletme yönetimi ve yöneticisinin gelişen toplumsal talep ve teknolojik yenilikler karşısında daha esnek ve hareket kabiliyeti yüksek düzeyde işletme kararlanının oluşması için daha fazla çaba içerisinde olması gerekmektedir. İşletmelerin yönetiminde doğrudan yer almasa da, onları yönlendirme kabiliyeti ve kapasitesine sahip olan yeminli mali müşavirlerin, yön gösterici rolleri ile işletme içerisinde ya da işletmenin dışında bulunmak kaydıyla faaliyetleri planlı olarak denetlemeleri ve devamındaki sorumluluklanı büyüktür. Karar alma süreçlerinin sağlıklı yürütülebilmesi için gerek yasal, gerekse işletme dinamiklerini yönlendirici özelliğe sahip olan yeminli mali müşavirler (YMM), etkin bir işletme yapısı için yönetsel kararların eş zamanlı olması doğrultusunda çaba sarf ederler.

$\mathrm{Bu}$ çalışma, işletmelerin dışarıdan hizmet aldığ ya da bünyesinde çalıştırdığı YMM’lerin bilgi ve tecrübelerinden ne ölçüde yararlandığını araştırmaya yöneliktir. Çalışmada izlenilecek yol haritası şu şekilde çizilmiştir; yönetim muhasebesinin işletmelerdeki önemi doğrultusunda görevleri literatür araştırmasında belirlenecek, yeminli mali müşavirlik mesleği hakkında bilgi verilerek yönetim muhasebesinin işletmelerdeki önemi doğrultusunda görevleri, literatür araştırması sonucu tespit edilecek, tespit edilen yönetim muhasebesinin görevlerinin mevcut düzeyde işletme yeterliliği ve bu işletmelerin YMM’lerden ne derecede destek sağlayabildikleri sorularının cevabına yapılacak anket uygulama sonuçlanı ve analizler ile ulaşılacaktır.

\section{Yeminli Mali Müşavirlik Mesleği ve Kapsamı}

Muhasebe mesleğinin 1989 yılında yayınlanan 3568 Sayılı yasa ile kişilik kazandı̆̆ını söyleyebiliriz. Yasanın 2. maddesinde ülkemizde YMM'lerin yapabilecekleri işler sıralanmıştır. Bu yasaya göre: işletmelerin muhasebe sistemlerini kurmak, geliştirmek, muhasebe ve finans konulannnda işletmelere yardımcı olarak onlara müşavirlik hizmetlerinde bulunmak YMM'lerin görevleri arasındadır, aynı zamanda yukarıda belirtilen unsurlara ek olarak buralarda kullanilan belgelerin yasalara uygunluğu konusunda da işletmelere yardımcı olmak durumundadırlar. YMM'ler, işletmelerin mali tablolarını tahlil etmek, denetim işlemlerini yerine getirmek gibi konularda da işletmeye yardımcı olmaktadır.

Yeminli mali müşavirler gerçek veya tüzel kişilerin veya bunların teşebbüs ve işletmelerinin mali tablolarının ve beyannamelerinin yasalarla, muhasebe prensipleri ile muhasebe standartlarına uygunluğunu sağlar. Hesapların denetim standartlarına göre incelendiğini tasdik ederler.

YMM’ler Bakanlığın izni kapsamında tasdik işlemini gerçekleştirirler. 03.01.1990 Tarih ve 20391 sayılı Resmi Gazetede yayınlanan "Yeminli Mali Müşavirlerin Çalışma Usul ve Esasları Hakkında Yönetmelik", in 19/d maddesinde "İgili mevzuat ile Maliye Bakanlı̆̆1 ve Resmi mercilerce verilecek görevleri yapmaktadır" ibaresi kullanılmıştır. Burada ifade edilen resmi merciler, ilgili bakanlıklar, kurumlar ve kuruluşlar olarak belirtilebilir(Sanayi Bakanlığı, Sermaye Piyasası Kurulu, Sanayi Odaları, YÖK, Tarım Bakanlığı vb. sıralanabilir).

Modern yönetim muhasebesi yöntemleri mevcut muhasebe profesyonellerinin artık sadece muhasebe kayıtlarını tutan veya yöneten olmalarının yanında stratejik karar sürecine desteklerini zorunlu hale getirmiştir (Sedgley \& Jackiw, 2001, s.4). Şirket içerisinde yönetim muhasebesini uygulayan bireyler, geleneksel muhasebeci rolünden arınmalıdır. Modern yönetim muhasebesi uygulayıcılan, üst düzey 
yönetimin ihtiyaç duyduğu muhasebe verilerini karşılamanın yanında, stratejik yönetim muhasebesi sisteminin uygulanabildiği bir sistemin oluşturulması ile organizasyonun hedeflerinin gerçekleştirilmesine yönelik motive edici birer aktöre dönüşmelidir (Devie v.d., 2008, s. 91). Fakat mevcut piyasa, yönetim muhasebesinin görevlerini alg1layacak ve geleneksel muhasebecilikten çok modern muhasebe algisına sahip işletme yöneticileri ve uzman personel konusunda yetersiz kalabilmektedir. Bu durumda ekonomik sistem içerisinde yer alan profesyoneller, muhasebe sisteminin bilimsel anlamda kullanılması için sektörlere destek vermelidir. $\mathrm{Bu}$ ifade doğrultusunda muhasebe profesyonelleri olan yeminli mali müşavirlere önemli görevler düşmektedir. Yeminli mali müşavirler sadece sistemin istediği vergisel muhasebe yükümlülügü doğrultusunda işlevlerini sunma eğiliminden kurtularak modern muhasebe algisına hizmet sağlayacak şekilde işletmelerin stratejik kararlarını destekleyici yükümlülüklerini de ortaya koyarak bilgi birikimlerini sektöre aktarmalıdır.

\section{Literatür Araştırması ile Tespit Edilen Yönetim Muhasebesinin Görevleri}

Yönetim muhasebesi, planlama ve karar alma süreçlerinde işletme yönetimlerini destekleyen, onları kontrol altında tutan muhasebe sistemidir. Geçmiş ve cari dönem bilgilerini sayısal verilerle ortaya koyan yönetim muhasebesi, işletmelerin gelecek planlamaları ve karar alma aşamalarında rasyonel karar vermelerini sağlayacak değerleri işletme yönetimlerine sunar. $\mathrm{Bu}$ yönüyle yönetim muhasebesi organizasyonel hedeflere ulaşılması için kontrol görevini üstlenen yönetim sürecinin ayrılmaz bir parçasıdır (Dekker, 2016: 86). Özellikle işletmelerin gelişme ve değişme süreçleri ile birlikte yönetim süreci daha kompleks bir hal alacak ve buna bağlı olarak yönetim muhasebesine olan ihtiyaç da artacaktır (Sunarni, 2013, s. 1).

Yönetim muhasebesinin işletmelerdeki sağlayacağı yararları ortaya çıkaran görevlerinin aslında yönetimin temel işlevleri olan planlama, örgütleme, yürütme ve denetleme ile bağlantılı olduğu görülmektedir. Yönetim muhasebecisi tarafindan hazırlanan geçmişe dönük raporlar, o günkü veya yakın geçmişteki durumu ortaya koyarak geleceğe yönelik planlama çalışmalarına ışık tutmaktadır. Bu aşamada ortaya konulan finansal tablolara bağlı olarak yapılan performans analizleri, maliyet değerlendirmeleri vb. raporlar yer almaktadır. Mevcut durumun tespitini takip eden süreçte ise geleceğe yönelik tahmin ve planlamalar gelmektedir. Yine burada yönetim muhasebesi araçlan olan bütçeleme, hedef maliyetleme, sabit varlık yatırım planlamaları vb. planlama ögeleri kullanılmaktadır.

Günümüzde yönetim muhasebecisi, şirket genelinde yer almakta ve Ar-Ge, tasarım, üretim, pazarlama, dağıtım ve tüketici hizmetleri gibi organizasyona çeşitli hizmetler sunan kişilerden oluşmakta ve bu alanlarda üst yönetime düzenledikleri raporlar1 vermektedirler (Bamber vd., 2008, s. 8).

Yönetimin örgüt yapısı arasındaki ilişkilere bakıldığında ise yukanıda da değinildiği gibi özellikle üst düzey yönetim muhasebecisinin sorumluluk sınırları içinde olan liderlik, motive ve iletişim ön plana çıkmaktadır. Bu aşamada taktiksel kararlar, yönetim bilgi teknolojilerinin işletme birimleri içerisinde verimli kullanımı ve birimlerin birbirleri ile koordinasyonu gibi konular temel odak noktasını oluşturmaktadır.

İşletmelerde denetleme fonksiyonu, yönetim muhasebesi araçlarının en yaygın kullanıldığı alan olarak tanımlanabilir. Özellikle planlama aşamasında ortaya konulan hedeflerin gerçekleşme düzeyleri bu işlevin temel yapı taşlarındandır. Örneğin planlama aşamasında oluşturulan bütçelemenin kontrolü ve meydana gelen sapmalar, belirlenen standart maliyetlerin gerçekleşme dereceleri, karlllık hedeflerinin ne derece başarılı olduğu gibi konuların yanında işletmenin tüm birimlerini ilgilendiren balanced scorecard değerlendirmeleri denetleme fonksiyonu kapsamında yer alan bazı yönetim muhasebesi araçları ve amaçları olarak karşımıza çıkmaktadır.

Geleneksel yönetim muhasebesi içe dönük bir yapiya sahiptir. Stratejik planlama ve stratejik uygulamanın temelini oluşturan stratejik kararlara yardımcı bir yönetim muhasebesi ise, içe dönük uygulamaların yanında dış çevre ile etkileşimi sağlayacak uygulamaları da gerçekleştirmelidir. Bu açıdan ekonomik, teknolojik, sosyal ve siyasal değişimler, bunların mali açıdan işletmelere etkileri, müşteri ve tedarikçi ilişkileri, ürün portföyü, fiyatlar, talep piyasası v.b. konularda da bilgiler toplanarak stratejik kararlara etkili analiz ve raporlar sağlanmalıdır (Ergin \& Elmac1, 1999, s. 18). Zira günümüzde değişen şartlar kapsamında işletme dinamiklerini harekete geçirecek stratejik bir yönetimin iç dinamikleri yanında dış dinamikleri ve çevresinin de güçlü olması beklenmektedir. 
Yönetim muhasebesi işlevleri göz önüne alınarak, işletmelerin yönetim muhasebesi kullanımlarını tespit etmek çalışmanın esas konusunu oluşturmaktadır. Bu görevlerin algılanması ve bu görevler doğrultusunda yönetim muhasebesi sisteminin kurgulanabilmesi için, ya işletme içinde yönetim muhasebesinden elde edilecek bilgiyi kullanabilecek profesyonellerin mevcut olması ya da dişardan bu desteği sağlayacak profesyonellere ihtiyaç duyulacaktr.

Yönetim muhasebesi ileri derecede muhasebe bilgisi gerektirmektedir. İşletmelerde yönetim muhasebesi uygulamaları önündeki en önemli engellerden birisi ise yönetim muhasebesi sistemini uygulayabilecek uzman personel yetersizliğidir. Bu konudaki yetersizliklerini gidermek için işletmeler, işletme dışından profesyonel yardım alabilirler. Uzman personeller, ekonomik sistemin içerisinde yer alan meslek mensupları olarak mali müşavirler ve yeminli mali müşavirlerdir. Çalışmada muhasebe meslek mensupluğu açısından en üst seviyede bilgi birikimine sahip olduğu kabul edilen YMM'ler analizlere dahil edilmiştir.

Yönetim muhasebesinin işletmelere sağlayacağı yararların tespit edilebilmesi için öncelikli olarak görevleri tespit edilmelidir. Daha sonra bu görevler, faaliyetlerin gerçekleştirilmesi ile işletmelerin karakteristik yapılarına uygun muhasebe sisteminin geliştirilmesine destek olacaktır.

İşletme yönetiminin önemli işlevlerinden birisi kontrol işlevidir. İșletmelerde kontrol işlevini gerçekleştirecek önemli faaliyetlerden birisi ise performans ölçüm ve yönetimleridir. İşletmelerin performans ölçümleri; işletmelerin doğrudan veya dolaylı yolla mali yönden olumlu etkisini ortaya çıkaran belirli bir amaca haiz ve planlanmış örgütsel faaliyetlerindeki niteliksel ve niceliksel olarak meydana gelen olumlu eylemlerdir (Neely vd., 1995, ss. 80-81). Bir başka ifade ile performans ölçümü, mevcut işletme kaynaklarının etkin ve verimli bir şekilde kullanılması suretiyle daha önceden tespit edilmiş olan amaçlara ulaşabilme yetisi veya işletmenin belirli bir süreç sonunda elde edilen çıktı ya da sonuçlardır (Hanzlick, 2015, s. 34). Performans ölçümü ile elde edilecek sonuçlar; yöneticilere gelecekte karşılaşacakları fırsatlardan yararlanmalarını sağlaması, kaynakları daha etkin kullanmalarını sağlamak yanında işletmeyle ilişkili olan diğer gruplanın da işletme ile ilgili verecekleri kararlarda yön gösterici olmaktadır (Hilton, 2005, s. 6). Yönetim muhasebesi, yöneticilerin stratejik hedefleri gerçekleştirme ve karar alma aşamalarında kontrol sürecini performans ölçümleri aracilğ̆ ile gerçekleştirmektedir (Rachman, v.d., 1996, s. 170). Yönetim muhasebesi işletmelerde performans ölçümlerini sağlamak adına performans karnelerinin düzenlenmesi, oran analizlerinin yapılması, mali tabloların analizlerinin gerçekleştirilmesi gibi yöntemlerle bu görevi icra etmektedir. İngiltere'de bulunan iki önemli muhasebe enstitüsü Chartered Institute of Management Accountants (CIMA) ve Institute of Chartered Accountants of Scotland (ICAS); yönetim muhasebesi konusunda uzman olan yeminli mali müşavir ve mali müşavirlerin, işletmelerin performans yapılarını mali açıdan muhasebe ve piyasa temelli olarak ölçümleyebildikleri ve işletme yönetimlerinin, stratejik hedeflere ulaşmak için kontrol sağlayacak ihtiyaç duydukları bilgilere ulaşabildikleri etkin bir performans ölçüm sisteminin oluşturulmasına yönelik aktif bir rol üstlenmeleri gerektiğini ifade etmektedirler (Neely, 1999, s. 218).

Her ne kadar geleneksel yönetim muhasebesi anlayışı maliyet analizi üstüne kurulmuş olsa da modern yönetim muhasebesi anlayışında finansal kontrol de ön plana çıkmaktadır. (Ovunda, 2015, s. 1890) Finansal kontrol: işletmelerin finansal yönetim sürecinin sağlıklı işletilebilmesi için ve hedeflenen finansal planların gerçekleştirilebilmesi için yapılan kontrollerdir. Finansal kontrolün amacı, işletme kaynaklarının etkin ve etkili bir şekilde varlıklara dönüştürülüp dönüştürülmediğinin tespit edilmesi, işletme sahiplerinin çıkarlarına uygun faaliyetlerin gösterilip gösterilmediğinin denetlenmesi ve işletme karı ve karlılığının devam ettirilmesi amacı ile yapılan faaliyetlerin dürüstlüğünü incelemektir.

İşletme kontrol sürecinde yöneticilere yardımcı olacak unsurlardan birisi de maliyet kontrolüdür. Maliyet kontrolünün amacı işletmelerde karı artırmak amacı ile işletme giderlerinin belirlenerek minimuma indirilme sürecidir. Günümüzde yönetimler, hızla artan rekabet nedeniyle hayatta kalma problemleriyle karşı karşıya kalmaktadırlar. Yalnızca etkin maliyet kontrolü yapan kuruluşlar rekabeti hazırlıklı bir şekilde karşılayabilir ve maliyetlerini minimumda tutarak piyasaya hakim olabilirler. Maliyet odaklı bir yaklaşımı benimseyen işletmelerde, yönetim muhasebesi aracıllğı ile yapılan maliyet analizleri, tüm verimsizlikleri ve israfları ortadan kaldırarak işletmeler için etkili bir araç olarak kullanılmaktadır (Okutmuş v.d., 2014, s. 65). 
Yönetim muhasebesi, maliyet yönetim ve kontrolünü son dönemlerde literatürde de oldukça sık karşılaşılan faaliyet tabanlı maliyetleme, hedef maliyetleme, Kaizen maliyetleme v.b. yöntemleri kullanarak gerçekleştirmektedir. Karar alma sürecinde daha spesifik verilere ulaşılması için de bu yöntemlerin kullanıldığ1 görülmektedir (McWatters \& Zimmerman, 2016, s. 103).

İşletme yönetiminin geçmişten günümüze temel görevlerinden birisi karlllı̆̆1 artırmaya yönelik çalısmalarıdır. Geleceğe ilişkin kar planlamasının gerçekleştirilmesinde gelir kadar önemli olan maliyetler ve işletme kapasite yönetimidir. Yönetim muhasebesi maliyet-hacim-kar analizleri yaparak yöneticilerin gelecek planlamalarına yardımcı olmaktadır (Lazol, 2004, s. 237).

Modern yönetim muhasebesi sistemleri, işletmelerin karll11k analizleri yapma ve bu sayede yöneticilerin karar alma süreçlerinde yardımcı olmasını amaçlamaktadır (Dávila vd., 2015, s. 116).

Bütçeler; işletme yöneticilerinin belirledikleri vizyon, misyon, politika ve stratejiler doğrultusunda işletmelerin geleceğine yön veren, kısa orta ve uzun vadede işletmelerin faaliyetlerini önceden planlanan şekilde, üretim ve satışın aksamadan yürütülmesini sağlayan ve böylece işletmelerin nihai hedeflerine ulaşmalarında büyük önem taşıyan yönetimsel araçlardır.

Bütçeleme faaliyetlerinin işletmelere sağladığ1 katkılar maddeler halinde şu şekilde özetlenebilir:

- İşetmeler hazırladıkları bütçeler sayesinde, amaçlarını ve hedeflerini tespit eder.

- Hedefledikleri durum ile gerçekleșen durum arasındaki sapmaları ve nedenlerini tespit ederek gerekli düzeltme işlemini yapar ve ileriye yönelik önlemlerini alır.

- Daha akılcı ve sağliklı sonuçlar elde edilir.

- Mevcut olanaklarla neler yapılabileceğini ve bu konudaki en doğru ve verimli yolu gösterir.

- Hedeflere ulaşmak için ilerlenen yolda nelere katlanılacağını gösterir.

- İşletmenin sahip olduğu kaynakları en etkili şekilde kullanma olanağı sağlar.

- Yönetimin sağlıklı ve doğru karar almasına yardımcı olur.

Bir işletmede duran varlıklara yapılan yatırımlar sermaye harcamaları olarak adlandırılmakta, yatırım planları (sermaye harcamalarının planlanması) ise sermaye bütçelemesi olarak bilinmektedir. Sermaye bütçelemesi; uygun ve verimli yatıım alanlarının araştırılması ve sermaye harcama önerilerinin (yatırım projelerinin) değerlendirilmesidir.

Diğer bir ifadeyle sermaye bütçelemesi, yeni, karlı, verimli yatırım projelerinin araştırılmasını, bir yatırım önerisinin kabul edilmesinin etkilerini tahmin edebilmek için teknik ve pazarlamaya hatta yönetime ilişkin tüm etmenlerin incelenmesini, her yatırım önerisinin kar sağlama potansiyelini belirlemek için ekonomik analiz yapılmasını içeren çok yönlü bir faaliyet olarak tanımlanabilir (Akgüç, 1994, s. 320).

Ekonomik gelişme ile birlikte işletmelerin çalışma alanları oldukça artmakta ve bu süreç rekabet ortamını da beraberinde getirmektedir. İşletmelerde meydana gelen bu yapısal gelişme aynı zamanda onların bilgi ihtiyaçlarını da ortaya çıkarmaktadır.

İşletmelerin amaçlarına ulaşabilmeleri için ihtiyaç duydukları bilgilerin bir değere sahip olması beklenir. Bir kısım bilgiler, işletme için son derece önemli ve aynı zamanda stratejik bir değere sahip olacaktır. Bilginin zamanlı ve verimli kullanılabilmesi işletme yönetimi kadar, bu sistemi koordine edecek bir sistem olan yönetim muhasebesinin uygulayıcılarının da görev alanına girmektedir.

İşletmenin temel işlevlerinden olan yürütme fonksiyonu içerisinde yönetim muhasebesinin çok yeri olmadığ1 düşünülse de aslında her aşamada muhasebe bilgi sistemi tarafindan üretilen verilere ihtiyaç duyulduğu da bir gerçektir. Örneğin tam zamanında üretim yöntemini kullanan bir işletmenin üretim akışının sekteye uğramaması bu verilere bağlı olmaktadır.

Kurumsal işletmelerin önemli bir kısmı bütünleşik bilgi sistemi kullanmaktadır. Bütünleşik bilgi sistemleri işletmelerin birçok fonksiyonlarının ortaya çıkardığı bilgileri bir araya getiren aynı zamanda web aracilığ ile dışarıdan bilgi ile destekleyen veri tabanlarıdır. Iş̧lem ve analize dayalı bu sistemlerin önemli bir parçasını yönetim muhasebesi oluşturmaktadır (Demir, 2008, s. 11).

$\mathrm{Bu}$ analizler, müşteri ilişkileri sayesinde müşterinin gelecekteki kazanımlarını düşünerek daha sağlam geleceğe dönük bir talep piyasası oluşturmayı ifade eder. Mevcut süreç rekabet ortamında karlılı̆̆1 maksimize etme konusunda müşteri önceliğini ön planda tutmayı bir zorunluluk haline getirmiştir. Artık işletmeler müşterilerine önem vermekte lakin müşterilerini karlıllğı doğrultusunda ayırt etmektedir. Çünkü bazı müşteriler az gelir getirirken bazı müşterilerin karlllığ istenilen düzeyin de üstünde olabilmektedir 
(McWatters \& Zimmerman, 2016, s. 144). İşletme müşterilerinin isteklerini karşılayıp karşılayamadığını belirlemek, yani onların arzu ettikleri malların ve hizmetlerin sunulup sunulmadığını öğrenmek için muhasebe verilerinden faydalanmalıdır (Parker, 2000, s. 63). Müşterilerin farklı istek ve ihtiyaçları yanında gelir seviyeleri ve harcama eğilimleri onların karlılığını belirleyen en önemli özelliklerdir. Yönetim muhasebesi bu ve benzeri bilgileri yöneticiye sunabilecek şekilde dizayn edilmelidir (Hilton \& Platt, 2014, s. 185).

Geleneksel muhasebe anlayışı, işletme müşterilerinin karlılığı aynı oranda etkilediğini kabul etmektedir. Yönetim muhasebesi geleneksel muhasebe anlayışından farklı olarak müşteriler özelinde karlılık analizleri yapar. Bu sayede müşteri karlılığını çeşitli unsurlar doğrultusunda analiz ederek spesifik bilgiler sunar. Bu bilgiler, işletme yönetimleri tarafından karlı müşterilere yönelik üretim imkanlarının geliştirilmesine ve karlılığın maksimize edilmesine imkan sağlamaktadır (Kaplan \& Anderson, 2007, s. 5).

Müşteri kârlllık analizleri yapan işletmeler yönetim muhasebesi ve maliyet muhasebesinden elde ettiği verileri kullanarak müşteri ve pazar özelinde sınıflandırma yapmakta ve bu sınıflandırma doğrultusunda karlılık analizlerinin yapılmasına imkan sağlanmaktadır. Bu durum stratejik kararların alınmasında yöneticinin elini kuvvetlendirmektedir.

İşletmelerde stratejik, operasyonel ve taktiksel olmak üzere üç farklı karar alma yönteminden bahsedilebilir. Stratejik kararlar geleceğe yönelik alınan kararlardır ve belirsizlik seviyesi oldukça yüksektir. Organizasyonun amaçlarının tespit edilmesi ve bu amaçlara ulaşmak için uzun dönemli planlar yapılmasını sağlar. Operasyonel kararlar taktik seviyedeki kararların yürütülmesi için gerekli görevlerin etkin ve verimli bir biçimde yapılmasına imkan sağlar. Taktik karar alma ise stratejik seviyede alınan kararların uygulanması ve kaynakların etkin ve verimli kullanılmasına yönelik karar alma yöntemleridir.

Yönetim muhasebesi, organizasyonun stratejik hedeflerine ulaşmak için alacağ stratejik kararlara yardımcı olarak yöneticiler tarafindan ihtiyaç duyulan operasyonel ve taktiksel kararların oluşturulmasına yönelik bilgiler sağlayan ve bu kararların uygulamaya geçirilmesi için gerekli yapıyı oluşturan muhasebe sistemidir. (Miko, 1998, 53-54; Hilton, 2005, s. 6). Modern yönetim muhasebesi anlayışı, işletmenin bütün karar alma süreçlerinde kullanılacak uygulamaların geliştirilmesine yönelik yönetim muhasebecilerinin etkin görev üstlenmeleri gerekliliğini ortaya koymaktadır. (Li, 2018; ss. 2-3). Bu amaçla sistem içerisinde yönetim muhasebesi ile elde edilecek verilerin işlenmesini ve yönetim muhasebesini bilimsel açıdan kullanma yetisine sahip uzman bir ekibin oluşturulması ve bu ekip tarafindan yönetim muhasebesi ile karar alma süreci ve gelecek planlamamalarına yardımcı bir veri sisteminin oluşturulması gerekir. Yönetim muhasebecisi bu yönüyle karar alma süreçlerinin etkinliğini sağlayacak organizasyon içerisinde önemli bir aktör olacaktır (Devie v.d., 2008, s. 93).

Etkinlik, verimlilik işletmelerin teknik anlamda performans göstergeleridir. Etkinlik, organizasyonun faaliyetlerinin sonucu olarak amaçlara ulaşma derecesini belirleyen bir performans boyutudur (Horngren, vd., 2000, s. 229). İşçilik, hammadde, malzeme ve diğer girdilerin amaçlar doğrultusunda ne ölçüde etkin ya da yeterli seviyede kullanıldığını gösterirken verimlilik, üretim sürecine dahil edilen girdiler ile bu süreç sonunda elde edilmiş olan çıktılar arasındaki ilişskiyi ifade eder. İşletmenin verimliliği aynı zamanda kontrollü bir şekilde kaynakları en optimum seviyede kullanmak anlamına da gelir. Girdi ve çıtı arasındaki ilişki çıtı/girdi olarak formüle edilir (Prokopenko, 2005, s. 19). Verimlilik, işletmelerde operasyonel yönetim etkinliğinin belirlenmesine yönelik önemli bir ölçüttür. Bütçe hedefleri doğrultusunda üretim kapasitesi, çıktıların tahmini, kaynak gereksinimleri ve maliyet tahminlerinin yapılması için belirli dönemler halinde yönetim muhasebesinden elde edilen veriler doğrultusunda birim bazlı toplantıların yapılması sağlanmalıdır. Bu sayede işletmenin genel performansı ve birim bazlı performans ölçümleri gerçekleştirilerek işletmelerde etkinlik ve verimliliğin sağlanacağı bir yapı oluşturulacaktır.

Ürün kalite yönetimi; müşteri ihtiyaç ve isteklerinin tatminini gerçekleştirmektir. Bu yönetim süreci operasyon performansının iyileştirilmesi, maliyetlerin düşürülmesi vb. amaçlar için kullanılmaktadır. Ürün kalite yönetiminin gerçekleştirilmesi işletmelerin gelecek planlamalarında en önemli yap1 taşı olan talep piyasasının korunması ve geliştirilmesi amacı ile de kullanılacaktır. Kalite mevcut müşteri sadakatini sağlarken aynı zamanda yeni talep oluşumunu da sağlayacaktır.

Yönetim muhasebesi sistemi, işletmelerin kalite hedefleri ve maliyetleri hakkında yeterli veriyi sağlayacak yapıda olmalıdır (Yükçü \& Doğanöz, 1994, s. 72). Bu sayede kalite maliyetlerinin 
ölçümlenebilmesi ve kontrol edilebilmesi mümkün olabilecek ve yönetimin karar alma sürecinde kalite, fiyat ve müşteri arasındaki ilişkinin belirlenmesine yönelik mantıklı kararlar almasına imkan sağlayacaktır.

Çıktı kalitesinin yönetimini en iyi şekilde anlatan sistem Toplam Kalite Yönetim sistemidir. Bu sistem müşteri beklentilerini ön planda tutarak müşterinin alg1sı olan kaliteyi bütün işletme faaliyetlerinin yürütülmesi esnasında dikkate alan bir yönetim tarzıdır (Ertuğrul, 2014, s. 85). Müşterinin kalite algısını kalite maliyetlerini oluşturarak işletmeye en az maliyetle istenilen kaliteye ulaşma firsatı veren bu sistem modern yönetim muhasebesinin ana görevlerinden birini yerine getirmektedir. Kalite yönetiminin uygulamaya geçirilmesi ile ürün ve hizmet kalitesi artırllırken kalite maliyetlerinde de azalma sağlanacak ve sonuç olarak düşük maliyetle iyi kalite sağlanarak müşteri tatmini ve pazar payı artırlacaktır.

İşletmelerde kontrol ve denetim sürecinde etkili olarak kullanılabilecek bir yöntem de sapma analizleri yapmaktır (Yalçın, 2009, s. 300). Sürekli iyileştirme çalışmaları, şirketlerin planlamadan üretim sürecinin sonuna kadar yapılan hatalardan ders çıkarılarak daha iyisini elde etmeye yönelik gerçekleştirilen eylemlerdir. Planlanan çıktının nicelik olarak değerinin yanında kalitesinin, üretim zamanının, değer yaratma gücünün istenilen şekilde olması açısından sürekli iyileştirilerek plan ve sonuç arasındaki farkları asgariye indirgemek hatta ortadan kaldırmaya yönelik çalışmaların yapılması ve bu sayede verimliliğin sağlanması yönetim muhasebesinin görevlerinden birisidir. Modern yönetim muhasebesi yöntemlerinden birisi olan kaizen maliyetleme sistemi sürekli iyileştirme sistemi olarak da ifade edilir. Bu sistem işletme yöneticilerinin planlama ve bütçeleme sistemine yardımcı olarak kar planlamasında etkin bir rol üstlenir (Monden \& Lee, 1993, s. 26). Kaizen maliyetleme sisteminin her işletmede uygulanması kısa vadede mümkün olmasa bile sapmaların kontrolüne yönelik sürekli iyileştirme çabalarının önemini göstermesi açısından dikkat çekicidir.

Sunarni 2013 yllında yapmış olduğu bir araştırmada yönetim muhasebesinin görevlerini; işletme performanslarını değerlendirmek, finansal maliyet kontrolü, karlılığı artırma, bütçeleme, sabit varlık yatırım planlaması, taktiksel kararlar, üretkenlik/etkinlik geliştirme, müşteri değerini artırmak, ürün kalite yönetimi, ürün geliştirme çalışmalanı, müşteri ilişkilerini geliştirme ve yönetim bilgi teknolojileri olarak belirlemiştir (Sunarni, 2013, s. 621).

Sunarni'nin de tespit ettiği bu görevlere ilave olarak müşteri istek ve ihtiyaçlarnna uygun bir üretim devamlılığ1 için yönetim muhasebesinden elde edilen veriler tedarikçi ilişkilerinin yönlendirilmesi ve geliştirilmesi için kullanılmalıdır.

İşletmelerin müşteri istek ve düşüncelerindeki değişime bağlı olarak organizasyon yapılarındaki değişim pazardaki talep ve müşteri istekleri ve tedarikçilerin kazan kazan politikalarnna uygun şekilde belirlenecektir (Dellman \& Franz, 1994, s. 16). Mevcut müşterilerle olan ilişkilerin gücü bu istek ve ihtiyaçların önceden tespitine imkan sağlayacaktır. Aynı zamanda mevcut müşterilerin ihtiyaçları ve istekleri doğrultusunda mal ve hizmet sunumu yeni müşterilerin kazanımına da imkan sağlayacaktır. Yönetim muhasebesi kantitatif ölçümler yanında kalitatif değerleri de kullanmaktadır (Edmonds vd., 2000, s. 4). Müşteri kavramı da talep olması ve aynı zamanda satışı ortaya çıartan asli unsur olması açısından yönetim muhasebesinin önem verdiği bir konudur.

İşletmelerin gelecek planlamasına etken unsurların değerlendirilmesinde, performans yönetiminde, maliyet analizlerinde, karlılık yapısında ve borçlanma yönetimi gibi unsurlarda tedarikçiler ile kurmuş olduğu ilişki önemlidir. Tedarikçilerin sağlayacağı ödeme avantajları, lojistik, hammadde devamlllŭı, rakiplere göre öncelik sağlanması gibi konularda tedarikçi ilişkilerinin geliştirilmesi gerekmektedir. (Folan \& Browne, 2005, s. 672) Örneğin bir yönetim muhasebesi uygulaması olan faaliyet tabanlı maliyetleme sisteminin işletmede uygulanmasında hem tedarikçi hem de müşteri ilişkileri ve işletmenin kurumsal kaynak planlamasının beraber kullanılması sistemi daha dinamik hale getirirken aynı zamanda işletmenin kişilere olan bağımlılığını azaltarak kurumsal çalışmasına imkan sağlamaktadır (Kaplan \& Anderson, 2007, s. 18).

Organizasyonun yaşamasını sağlayan fonksiyonların sistematik bir şekilde sürekli iyileştirilmesi için üst yönetimin öncülügünde müşteri odaklı bir yapı sergilemek suretiyle kalifiye personellerin seçilmesi ve bu bireylerin takımlar halinde organize edilmesi gerekir. Demokratik bir katılım ile organizasyon içerisinde maliyet oluşturacak unsurların asgari seviyeye indirgenmesine yönelik sürekli iyileştirmelerle sıfirlanmasını hedefleyen çalışmalar yapilmalıdır. 
Yönetim muhasebesi yöntemleri olan değer zinciri analizi, balanced scorecard, faaliyet tabanl maliyetleme süreçlerinin sağlıklı bir şekilde sürdürülebilmesi için müşteri ve tedarikçi ilişkileri yönetiminin ve bu ilişki sürecindeki elde edilecek verilere olan ihtiyaçtan dolayı yönetim muhasebesini uygulayan işletmelerde müşteri ve tedarikçi ilişkileri yönetiminin de gelişmiş olması beklenen bir gelişme olacaktır.

Yukandaki ifadeler doğrultusunda işletme yönetiminin karar alma sürecinde etkinliğini sağlayacak yönetim muhasebesinin görevleri şu şekilde tespit edilmiştir:

- İşletme performans ölçümlerini gerçekleştirmek

- Finansal kontrol

- Maliyet kontrolü

- Karlilik analizleri

- Bütçeleme

- Yatırim planlamalari

- Yönetim muhasebesinin uygulanmasina yönelik bilgi teknolojilerinin kullanılması

- Stratejik kararların alınmasında istatistiksel analizlerin yapılması

- Müşteri değeri yaratma analizleri

- Etkinlik ve verimliliğin tespitine yönelik dönemsel raporlar ve değerlendirmeler

- Ürün kalite yönetimi

- Ürün ve hizmet yaratma sürecinde sürekli iyileştirme çalışmaları

- Müşteri ilişkilerini geliştirmeye yönelik çalışmalar

- Tedarikçi ilişkilerini geliştirmeye yönelik çalışmalar

Çalışmanın bundan sonraki bölümünde bu görevler doğrultusunda işletmelerin bu görevleri yerine getirme yetisi ve bu görevlerin yerine getirilmesinde yeminli mali müşavirlerin etkinliği tespit edilecektir.

4. Konya Organize Sanayi Bölgesi'nde YMM Hizmeti Alan Firmaların Yönetim Muhasebesi Uygulama Gücü ve YMM'lerin Rolü

\subsection{Araştırmanın Amacı ve Önemi}

Yönetim muhasebesi; işletmelerde yönetim rolünü gerçekleştiren bireylerin karar alma sürecinde ihtiyaç duyduğu amaçlarına mahsus ve ayrıntı içeren verileri sağlayan özellikli bir muhasebe sistemidir. Bu sistemin işletmelerde optimum faydayı sağlayacak şekilde dizayn edilmesi yetkin muhasebe elemanlarının varlığı ile mümkün olabilecektir. Aynı zamanda bu sistemin oluşturulmasinda ve uygulanmasında, işletme dişından da uzman destek alınmalıdır.

Yeminli mali müşavirler, asli görevleri olarak muhasebe, finans ve mali konularda belgelere dayanmak sureti ile inceleme ve denetimi gerçekleştirme, kayıtlann, yasa ve yönetmelikler ile birlikte, muhasebe standartları ve prensiplerine uygun tutulduğunu inceleme ve onaylama görevlerinin yanında, işletmelerin muhasebe sistemlerini kurma ve geliştirme konularında da destek vermektedirler. Bu açıdan bakıldığında YMM'ler yönetim muhasebesi uygulamalarında bu sistem aracılığı ile elde edilecek verilerin yönetim faaliyetlerinde kullanılmasında dışarıdan destek sağlayacak ve bu işletmelere danışmanlık yapabilecek en amir özelliklere sahip mesleki uzmanlardır.

$\mathrm{Bu}$ çalışma Konya Organize Sanayi Bölgesi'nde (OSB) faaliyet gösteren işletmelerde yönetim muhasebesi uygulamalarının varlı̆̆ ve bu uygulamalarda YMM'lerin etkinliğini yönetim muhasebesi sisteminin görevleri doğrultusunda değerlendirmeyi hedeflemektedir.

\subsection{Araştırma Kapsamı ve Yöntemi}

Araştırmada Konya Organize Sanayi Bölgesi'nde faaliyet gösteren ve yeminli mali müşavir ile çalıştığ1 tespit edilen işletmelerin yönetim muhasebesi görevlerine uygun faaliyetleri gerçekleştirme güçleri ve bu faaliyetlerde yeminli mali müşavirlerden aldıkları desteklerin tespitine yönelik olarak veri toplamak amacı ile anket yapılmıştur.

Çalışmada, nicel veriye dayalı genel ve ilişkisel tarama modeli esas alınmıştır. Çalışmada kullanılan tarama ifadesi ise; evren içinde bir grubun, örnek ya da örnek evrenden modelleri taramaktır. Bu modeller, 
iki veya daha fazla değişken arasındaki birlikteliğin varllğını veya derecesini belirlemeye yönelik araştırma modelleridir (Karasar, 2012, s. 79).

Anketler YMM'lerle çalışan işletmeler içerisinde sistematik örneklem yöntemi kullanılarak seçilen 123 şirkete ulaştırılmış fakat şirket yönetim politikaları, bilgilerinin dısarıya aktarılmak istenmemesi ve anketlerde verilen cevaplann eksik olması dolayısı ile 57 işletmenin verileri analizlerde kullanılmıştır.

Anket formu 3 bölümden oluşmaktadır. Anket formunun birinci bölümünde şirketlerin genel durumunu ölçen bilgiler sorulmuştur. Anketin ikinci ve üçüncü bölümde literatür çalışması ile elde edilen yönetim muhasebesinin görevleri kullanılarak ölçekler olușturulmuștur.

Anketin ikinci bölümü işletmelerin yönetim muhasebesinin görevlerini ne derecede gerçekleştirebildiklerini ölçmeye yönelik olarak hazırlanmıştır. 5'li Likert Ölçeği’ ne göre hazırlanan bu bölümde 14 farklı görev doğrultusunda etkinlik 5 dereceli olarak (1: uygulanmamaktadır; 5: tam dereceli olarak uygulanmaktadır) ölçülmüştür.

Anketin üçüncü bölümünde ise bu görevlerin gerçekleştirilmesi sürecinde yeminli mali müşavirlerden alınan destekler 5'li Likert Ölçeği'ne göre (1: destek almıyoruz; 5: tam destek alıyoruz) gerçekleştirilmiştir.

$\mathrm{Bu}$ aşamaların gerçekleştirilmesine yönelik anket verileri SPSS programı ile analiz edilmiştir. Analizde; frekans, standart sapma, ortalama, Cross Table ve Wilcoxon Signed Rank (PASW) test yöntemleri uygulanmıştır.

\subsection{Araştırma Analizi, Bulgular ve Yorumu}

Araştırma ile ilgili analizler, bulgular ve bunların değerlendirilmesi ve yorumlanması bu bölümde ele alınacaktır.

\subsubsection{Anketin Güvenilirlik Testi}

Anketin güvenilirliğini test etmek amacı ile ikinci bölümde (işletmelerin yönetim muhasebesinin görevleri ile uygun faaliyetleri gerçekleştirme düzeyleri) ve üçüncü bölümde (yönetim muhasebesine uygun faaliyetleri gerçekleştirme düzeylerine YMM’lerin sağladığı destek dereceleri) güvenilirlik analizi yapılmıştır. Yönetim muhasebesinin görevleri doğrultusunda faaliyetleri gerçekleştirme düzeyleri ve bu faaliyetlerin gerçekleştirilme düzeylerinde YMM'lerden sağlanan destekler 5'li derecelendirme yöntemi ile değerlendirilmektedir.

Ölçeklerin iç tutarlılığının değerlendirilmesinde Cronbach Alpha Reliability Analiysis yöntemi kullanılmıştır. Bu yöntem dereceleme yapılan anket sorularının iç tutarlılıklarının ölçümünde kullanılan bir yöntemdir (Ercan \& Kan, 2004, s. 213). Cronbach Alfa testinin sonuçları şu şekilde değerlendirilmelidir (Yildız \& Uzunsakal, 2018, s. 19);

$0<\alpha<0.40$ ise güvenilir değil

$0.40<\alpha<0.60$ ise düşük güvenilirlikte

$0.60<\alpha<0.80$ ise oldukça güvenilir

$0.80<\alpha<1.00$ ise yüksek güvenilirlikte

Anket 2. bölüm ölçeğin iç tutarlılığ1 Cronbach Alpha değeri $\alpha=0,962$, Anket 3. Bölüm ölçek iç tutarllğ1 Cronbach Alpha değeri ise $\alpha=0,959$ olarak bulunmuştur. Ayrıca sorular arasındaki Corelation Matrix'leri incelendiğinde de birbirleri ile pozitif korelasyonlu sorular oldukları görülmektedir. Bu durum yönetim muhasebesinin görevleri ile ilgili her iki bölümde belirlenen faaliyetlere ilişkin ölçek ifadelerinin yüksek güvenilirlikte olduğu anlamına gelmektedir.

\subsection{2. Şirketlerin Genel Durumlarının Tespitine Yönelik Sonuçlar}

Şirketlerin genel durumlarını tespit etmeye yönelik elde edilen değerler Tablo 2'de verilmiştir. 
Tablo 2. Sirketlerin Genel Durumları

\begin{tabular}{|c|c|c|c|c|c|}
\hline Değişkenler & Dereceler & Frekans & Yüzde & S.S. & $\mathbf{X}$ \\
\hline \multirow{4}{*}{ İstihdam Edilen Çalışan Sayısı } & $11-50$ & 24 & 42,1 & \multirow{4}{*}{1,264} & \multirow{4}{*}{3,28} \\
\hline & $51-100$ & 8 & 14,0 & & \\
\hline & $101-150$ & 10 & 17,5 & & \\
\hline & $150+$ & 15 & 26,3 & & \\
\hline \multirow{8}{*}{ Faaliyet Sektörü } & Gida & 6 & 10,5 & \multirow{8}{*}{3,318} & \multirow{8}{*}{5,75} \\
\hline & Demir-Çelik & 21 & 36,8 & & \\
\hline & Plastik & 1 & 1,8 & & \\
\hline & Makine & 11 & 19,3 & & \\
\hline & Enerji & 2 & 3,5 & & \\
\hline & Ambalaj & 3 & 5,3 & & \\
\hline & Otomotiv & 10 & 17,5 & & \\
\hline & Metal İşleme & 3 & 5,3 & & \\
\hline \multirow{5}{*}{ Sektördeki Faaliyet Süreleri } & $1-10$ & 4 & 7,0 & \multirow{5}{*}{3,09} & \multirow{5}{*}{1,123} \\
\hline & $11-20$ & 13 & 22,8 & & \\
\hline & $21-30$ & 22 & 38,6 & & \\
\hline & $31-40$ & 10 & 17,5 & & \\
\hline & 40 üzeri & 8 & 14,0 & & \\
\hline \multirow{2}{*}{ İşletmelerin Hukuki Statüsü } & A.Ş. & 30 & 52,6 & \multirow{2}{*}{0,504} & \multirow{2}{*}{1,47} \\
\hline & Ltd. Şti & 27 & 47,4 & & \\
\hline \multirow{5}{*}{ Şirket Sermayesi } & $0-500.000$ & 1 & 1,8 & \multirow{5}{*}{3,04} & \multirow{5}{*}{0,944} \\
\hline & $501.000-1.000 .000$ & 14 & 24,6 & & \\
\hline & $1.001 .000-5.000 .000$ & 31 & 54,4 & & \\
\hline & $5.001 .000-10.000 .000$ & 4 & 7,0 & & \\
\hline & 10.000 .000 üzeri & 7 & 12,3 & & \\
\hline \multirow{3}{*}{ İşletmelerin Yıllık Satış Cirosu } & $1.001 .000-5.000 .000$ & 22 & 38,6 & \multirow{3}{*}{2,02} & \multirow{3}{*}{0,896} \\
\hline & $5.001 .000-10.000 .000$ & 12 & 21,1 & & \\
\hline & 10.000 .000 üzeri & 23 & 40,4 & & \\
\hline
\end{tabular}

İstihdam ettiği personel sayılarına göre işletmelerin \%42,1’i 11 ila 50 arası personel çalıştırmakta, $\% 26,3$ 'ü ise 150 üzeri personel istihdam etmektedir.

Ankete katulan işletmelerin farklı sektörlerde yer aldığ1 Tablo 2'de görülmektedir. İşletmelerin başlıca faaliyet gösterdikleri sektörler ise sırası ile \%36,8'i demir çelik, \%19,3'ü makine ve \%17,5'i otomotivdir. Sektördeki faaliyet süreleri incelendiğinde; 21-30 y1l arasında faaliyet süresine sahip olan şirketler, ankete katılan şirketlerin \%38,6'sını, 1 ila 10 yll arasında şirket faaliyeti olanlar \%7'sini oluştururken, 40 ve daha fazla yıldır faaliyet gösteren şirketlerin oranı ise \%14'tür. Hukuki statüleri açısından bakıldığında ise \%52,6’s1 Anonim Şirket ve \%47,4’ü Limited Şirket şeklinde teşkil olmaktadır.

İşletmeler şirket sermayeleri açısından incelendiğinde \%54,4’ü 1.000 .000 ila 5.000.000 TL aras1 sermayeye sahiptir. Y1llık satış cirosu olarak ise \%38,6's1 1.000.000 ila 5.000.000 TL arası y1llık satış cirosuna sahipken \%40,4’ü 10.000.000 ve üzeri satış cirosuna sahip olduğu görülmektedir.

\subsection{3. Şirketlerin Muhasebe Departmanları ve Personel Durumlarına Yönelik Sonuçlar}

Ankete katılan işletmelerin muhasebe departmanları ve personelleri ile ilgili bilgiler Tablo 3'te gösterilmiştir. 
Konya Organize Sanayi Bölgesi'nde Ymm Hizmeti Alan Firmaların Yönetim Muhasebesi Uygulama Gücü ve Ymm’lerin Rolü

Tablo 3. Muhasebe Departmanlarının ve Personelleri

\begin{tabular}{|c|c|c|c|c|c|}
\hline Değişkenler & Dereceler & Frekans & Yüzde & S.S. & $\mathbf{X}$ \\
\hline \multirow{2}{*}{ Muhasebe Departmanı Var mı? } & Evet & 53 & 93 & \multirow{2}{*}{0,258} & \multirow{2}{*}{1,07} \\
\hline & Hayır & 4 & 7 & & \\
\hline \multirow{5}{*}{ Muhasebe Finansman Alanında Çalışan Personel Sayısı } & 1 & 12 & 21,1 & \multirow{5}{*}{2.44} & \multirow{5}{*}{1.118} \\
\hline & 2 & 21 & 36,8 & & \\
\hline & 3 & 14 & 24,6 & & \\
\hline & 4 & 7 & 12,3 & & \\
\hline & $5+$ & 3 & 5,3 & & \\
\hline \multirow{6}{*}{ Muhasebe Finans Departman Personelinin Ĕ̈itim Durumu } & Lise Öncesi & 1 & 0,7 & \multirow{6}{*}{3,45} & \multirow{6}{*}{0,849} \\
\hline & Lise & 20 & 14,2 & & \\
\hline & Ön Lisans & 45 & 31,9 & & \\
\hline & Lisans & 65 & 46,1 & & \\
\hline & Yüksek Lisans & 10 & 7,1 & & \\
\hline & Doktora & 0 & 0 & & \\
\hline
\end{tabular}

İşletmelerin \% 93’ü muhasebe ve finansman faaliyetlerinin gerçekleştirildiği ayrı bir departmana sahiptir.

Ankete katılan işletmelerde muhasebe finansman faaliyetlerini yürüten personel sayılanı ve bu personellerin eğitim durumları incelendiğinde Tablo 3'teki bilgilere ulaşılmıştır.

İşletmelerin tamamında muhasebe finansman faaliyetlerini yürüten en az 1 personel bulunmaktadır. Genel durum itibari ile işletmelerin 2 ila 3 muhasebe - finansman personeli çalıştırdıkları görülmektedir. Muhasebe finans personelinin büyük çoğunluğu ön lisans ve lisans mezunlarından oluşmaktadır. Yönetim muhasebesi, muhasebenin bilimsel anlamda uygulanmasını gerektiren bir alandır. Bu konu bilimsel süreçte eğitim alan bireylere ihtiyacı ortaya koyar. Yüksek lisans mezunu bireylerin sayısın \%7,1 iken doktoralı personelin olmaması dikkat çekicidir.

\subsubsection{Yönetim Muhasebesi ile İlişkili Faaliyetlerde YMM Destekleri}

İşletme faaliyetleri ve yönetim muhasebesi ilişkisi içerisinde işletmelerin yönetim muhasebesi uygulama güçleri ve bu faaliyetlerde yeminli mali müşavirlerden aldıklanı destek dereceleri ile ilgili analizler bu bölümde gerçekleştirilecektir. Öncelikli olarak şirketlerin mevcut durumda yönetim muhasebesi uygulama güçleri tespit edilmiş daha sonra ise bu faaliyetlerle ile ilgili YMM'lerden almış olduklan destekler değerlendirilmiştir.

\subsubsection{1. Şirketlerde Yönetim Muhasebesi ile İlişkili Faaliyetlerin Gerçekleştirilme Dereceleri}

Şirketlerin yönetim muhasebesinin görevleri doğrultusunda faaliyetleri gerçekleștirme durumları 5'li derecelendirme şeklinde ölçümlenmiştir. Ölçümlemede işletme yetkililerinin ifadelere 1 = yapıllmamakta, 2 $=$ az dereceli, $3=$ orta dereceli, $4=$ iyi dereceli, $5=$ çok iyi dereceli olmak üzere 5'li bir derecelendirme doğrultusunda cevap vermeleri istenilmiştir. Verilen cevapların frekansları, yüzdeleri, ortalaması ve standart sapması 'Tablo 4' de gösterilmiştir. 
Tablo 4. Şirketlerin Yönetim Muhasebesinin Görevleri Doğrultusunda Yaptıkları Faaliyetleri Gerçekleştirme Dereceleri

\begin{tabular}{|c|c|c|c|c|c|c|c|c|}
\hline \multirow{2}{*}{ DEĞİŞKEN } & & \multicolumn{5}{|c|}{ DERECE } & \multirow[t]{2}{*}{$\mathbf{X}$} & \multirow[t]{2}{*}{ SS } \\
\hline & & 1 & 2 & 3 & 4 & 5 & & \\
\hline \multirow{2}{*}{ Finansal Kontrol } & $\mathrm{N}$ & 4 & 10 & 10 & 6 & 27 & \multirow{2}{*}{3,74} & \multirow{2}{*}{1,395} \\
\hline & $\%$ & 7,0 & 17,5 & 17,5 & 10,5 & 47,4 & & \\
\hline \multirow{2}{*}{ İşletme Performans Ölçümleri } & $\mathrm{N}$ & 3 & 12 & 10 & 6 & 26 & \multirow{2}{*}{3,70} & \multirow{2}{*}{1,375} \\
\hline & $\%$ & 5,3 & 21,1 & 17,5 & 10,5 & 45,6 & & \\
\hline \multirow{2}{*}{ Bütçeleme } & $\mathrm{N}$ & 12 & 8 & 9 & 12 & 16 & \multirow{2}{*}{3,21} & \multirow{2}{*}{1,521} \\
\hline & $\%$ & 21,1 & 14,0 & 15,8 & 21,1 & 28,1 & & \\
\hline \multirow{2}{*}{ Yatırım Planlamaları } & $\mathrm{N}$ & 13 & 12 & 7 & 8 & 17 & \multirow{2}{*}{3,07} & \multirow{2}{*}{1,580} \\
\hline & $\%$ & 22,8 & 21,1 & 12,3 & 14,0 & 29,8 & & \\
\hline \multirow{2}{*}{$\begin{array}{c}\text { Yönetim Muhasebesinin Uygulanmasına Yönelik } \\
\text { Bilgi Teknolojilerinin Kullanılması }\end{array}$} & $\mathrm{N}$ & 16 & 12 & 6 & 5 & 18 & \multirow{2}{*}{2,95} & \multirow{2}{*}{1,652} \\
\hline & $\%$ & 28,1 & 21,1 & 10,5 & 8,8 & 31,6 & & \\
\hline \multirow{2}{*}{ Maliyet Kontrolü } & $\mathrm{N}$ & 23 & 11 & 9 & 4 & 10 & \multirow{2}{*}{2,42} & \multirow{2}{*}{1,511} \\
\hline & $\%$ & 40,4 & 19,3 & 15,8 & 7,0 & 17,5 & & \\
\hline \multirow{2}{*}{ Karlilik Analizleri } & $\mathrm{N}$ & 28 & 6 & 8 & 8 & 7 & \multirow{2}{*}{2,30} & \multirow{2}{*}{1,500} \\
\hline & $\%$ & 49,1 & 10,5 & 14,0 & 14,0 & 12,3 & & \\
\hline \multirow{2}{*}{$\begin{array}{l}\text { Etkinlik ve Verimliliğin Tespitine Yönelik Dönemsel } \\
\text { Raporlar ve Değerlendirmeler }\end{array}$} & $\mathrm{N}$ & 26 & 14 & 8 & 5 & 4 & \multirow{2}{*}{2,07} & \multirow{2}{*}{1,260} \\
\hline & $\%$ & 45,6 & 24,6 & 14,0 & 8,8 & 7,0 & & \\
\hline \multirow{2}{*}{$\begin{array}{c}\text { Stratejik Kararların Alınmasında İstatistiksel } \\
\text { Analizlerin Yapılması }\end{array}$} & $\mathrm{N}$ & 33 & 8 & 6 & 3 & 7 & 200 & 1427 \\
\hline & $\%$ & 57,9 & 14,0 & 10,5 & 5,3 & 12,3 & 2,00 & 1,421 \\
\hline Ürün ve Hizmet Yaratma Sürecinde Sürekli & $\mathrm{N}$ & 36 & 12 & 3 & 2 & 4 & & \\
\hline İyileştirme Çalışmaları & $\%$ & 63,2 & 21,1 & 5,3 & 3,5 & 7,0 & 1,70 & 1,180 \\
\hline & $\mathrm{N}$ & 39 & 6 & 6 & 5 & 1 & 165 & 1094 \\
\hline Urün Kalite Yónetımı & $\%$ & 68,4 & 10,5 & 10,5 & 8,8 & 1,8 & 1,05 & 1,094 \\
\hline Mücteri Dĕ̌eri Yorotmo Anolinleri & $\mathrm{N}$ & 41 & 9 & 3 & 3 & 1 & 140 & 0.047 \\
\hline Müşterı Değerı Yaratma Analızlerı & $\%$ & 71,9 & 15,8 & 5,3 & 5,3 & 1,8 & $1,4)$ & 0,94/ \\
\hline 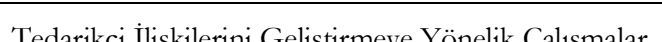 & $\mathrm{N}$ & 42 & 8 & 3 & 3 & 1 & 147 & 0.947 \\
\hline Tedarıç̧ı llışkılerını Gelıştırmeye Y onelık Çalışmalar & $\%$ & 73,7 & 14,0 & 5,3 & 5,3 & 1,8 & 1,47 & $0,94 /$ \\
\hline Müsteri İliskilerini Gelistirmeve Yönelik Calısmalar & $\mathrm{N}$ & 43 & 7 & 3 & 3 & 1 & & 0,946 \\
\hline Muşterı llişkilerını Gelış̧ırmeye Y onelık Çalışmalar & $\%$ & 75,4 & 12,3 & 5,3 & 5,3 & 1,8 & 1,40 & 0,940 \\
\hline Genel Ortalama & & & & & 37 & & & \\
\hline
\end{tabular}

İşletmeler yönetim muhasebesinin görevleri doğrultusunda orta düzeyde $(X=2,37)$ faaliyetler gerçekleştirdikleri tespit edilmiştir. Yönetim muhasebesinin görevleri doğrultusunda faaliyetlere genel olarak bakıldığında ortalamanın altında kaldığı $(X=2,37)$ görülmektedir. İşletmelerde yönetim muhasebesi görevleri doğrultusunda en etkin yapılan faaliyetler finansal kontrol, işletme performans ölçümleri, bütçeleme ve yatırım planlama, en az etkin olarak yapılan faaliyetler ise müşteri ve tedarikçi ilişkilerini geliştirmeye yönelik faaliyetler ve müşteri değer yaratma analizleri olduğu tespit edilmiştir.

\subsubsection{Faaliyetlerle İlgili Yeminli Mali Müşavirlerden Alınan Destek Dereceleri}

3. bölüm sorularda yönetim muhasebesi görevleri doğrultusunda gerçekleştirilen faaliyetlerde işletmelerin YMM'lerden destek alma düzeylerini derecelemeleri istenmiştir. Ölçümlemede, $1=$ destek alınmıor, $2=$ az dereceli, $3=$ orta dereceli, $4=$ iyi dereceli, $5=$ çok iyi dereceli olmak üzere 5'li bir derecelendirme gerçekleştirilmiştir. Verilen cevapların frekansları, yüzdeleri, ortalaması ve standart sapması Tablo 5'de gösterilmiştir. 
Tablo 5. YMM'lerden Destek Alma Düzeyi

\begin{tabular}{|c|c|c|c|c|c|c|c|c|}
\hline \multirow{2}{*}{ DEĞİŞKEN } & & \multicolumn{5}{|c|}{ DERECE } & \multirow[t]{2}{*}{$\mathbf{X X}$} & \multirow[t]{2}{*}{ SS } \\
\hline & & 1 & 2 & 3 & 4 & 5 & & \\
\hline \multirow{2}{*}{ İşletme Performans Ölçümleri } & $\mathrm{N}$ & 3 & 8 & 8 & 6 & 15 & \multirow{2}{*}{3,55} & \multirow{2}{*}{1,377} \\
\hline & $\%$ & 7,5 & 20,0 & 20,0 & 15,0 & 37,5 & & \\
\hline \multirow{2}{*}{ Finansal Kontrol } & $\mathrm{N}$ & 5 & 7 & 7 & 7 & 15 & \multirow{2}{*}{3,49} & \multirow{2}{*}{1,451} \\
\hline & $\%$ & 12,2 & 17,1 & 17,1 & 17,1 & 36,6 & & \\
\hline \multirow{2}{*}{$\begin{array}{l}\text { Yönetim Muhasebesinin Uygulanmasına Yönelik Bilgi } \\
\text { Teknolojilerinin Kullanılması }\end{array}$} & $\mathrm{N}$ & 4 & 9 & 5 & 5 & 8 & \multirow{2}{*}{3,13} & \multirow{2}{*}{1,432} \\
\hline & $\%$ & 12,9 & 29,0 & 16,1 & 16,1 & 25,8 & & \\
\hline \multirow{2}{*}{ Bütçeleme } & $\mathrm{N}$ & 6 & 6 & 3 & 3 & 7 & \multirow{2}{*}{2,96} & \multirow{2}{*}{1,594} \\
\hline & $\%$ & 24,0 & 24,0 & 12,0 & 12,0 & 28,0 & & \\
\hline \multirow{2}{*}{ Yatırım Planlamaları } & $\mathrm{N}$ & 6 & 9 & 7 & 5 & 6 & \multirow{2}{*}{2,88} & \multirow{2}{*}{1,386} \\
\hline & $\%$ & 18,2 & 27,3 & 21,2 & 15,2 & 18,2 & & \\
\hline \multirow{2}{*}{ Maliyet Kontrolü } & $\mathrm{N}$ & 12 & 3 & 3 & 0 & 10 & \multirow{2}{*}{2,75} & \multirow{2}{*}{1,818} \\
\hline & $\%$ & 42,9 & 10,7 & 10,7 & 0 & 35,7 & & \\
\hline \multirow{2}{*}{ Karlilik analizleri } & $\mathrm{N}$ & 29 & 13 & 7 & 2 & 6 & \multirow{2}{*}{2,25} & \multirow{2}{*}{1,578} \\
\hline & $\%$ & 46,4 & 25,0 & 7,1 & 0 & 21,4 & & \\
\hline \multirow{2}{*}{$\begin{array}{l}\text { Stratejik Kararların Alınmasında İstatistiksel Analizlerin } \\
\text { Yapılması }\end{array}$} & $\mathrm{N}$ & 13 & 1 & 3 & 0 & 5 & \multirow{2}{*}{2,23} & \multirow[b]{2}{*}{1,688} \\
\hline & $\%$ & 59,1 & 4,5 & 13,6 & 0 & 22,7 & & \\
\hline \multirow{2}{*}{$\begin{array}{c}\text { Etkinlik ve Verimliliğin Tespitine Yönelik Dönemsel } \\
\text { Raporlar ve Değerlendirmeler }\end{array}$} & $\mathrm{N}$ & 13 & 5 & 4 & 4 & 13 & \multirow{2}{*}{2,12} & 1451 \\
\hline & $\%$ & 50,0 & 19,2 & 15,4 & 15,4 & 50,0 & & 1,431 \\
\hline Ürün ve Hizmet Yaratma Sürecinde Sürekli İyileștirme & $\mathrm{N}$ & 12 & 5 & 2 & 1 & 3 & 204 & 1430 \\
\hline Çalışmaları & $\%$ & 52,2 & 21,7 & 8,7 & 4,3 & 13,0 & 2,04 & 1,430 \\
\hline Müsteri Dešeri Yoretmo Anolinleri & $\mathrm{N}$ & 12 & 2 & 4 & 0 & 1 & 174 & 1147 \\
\hline Muşterı Degerı Y aratma Analizlerı & $\%$ & 50,0 & 19,2 & 15,4 & 0 & 15,4 & 1,14 & $1,14 /$ \\
\hline & $\mathrm{N}$ & 12 & 3 & 3 & 0 & 1 & & \\
\hline Urun Kalite Yonetımı & $\%$ & 63,2 & 15,8 & 15,8 & 0 & 5,3 & 1,68 & 1,108 \\
\hline 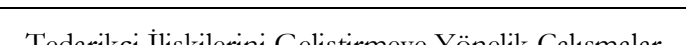 & $\mathrm{N}$ & 12 & 3 & 3 & 0 & 1 & & 1108 \\
\hline Tedarıç̧ı llışkilerını Gelıştrrmeye Yonelık Çalışmalar & $\%$ & 63,2 & 15,8 & 15,8 & 0 & 5,3 & 1,68 & 1,108 \\
\hline 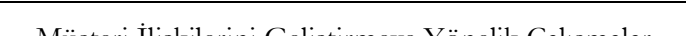 & $\mathrm{N}$ & 12 & 3 & 3 & 0 & 1 & 60 & 1100 \\
\hline Muşterı Illşkilerinı Gelışırmeye Yonellk Çalışmalar & $\%$ & 63,2 & 15,8 & 15,8 & 0 & 5,3 & 1,08 & 1,108 \\
\hline
\end{tabular}

Bir önceki bölümde işletmelerin faaliyetleri gerçekleştirme derecelerinin yeterli seviyede olmadı̆̆1 tespit edilmişti. Yönetim muhasebesinin belirlenen görevleri doğrultusunda faaliyetleri yeterli seviyede gerçekleştiremeyen bu işletmelerin, bu faaliyetleri gerçekleştirme süreçlerinde YMM'lerden ise orta dereceli bir destek aldıklan görülmektedir $(X=2,44)$. Bu durum faaliyetleri yeterli derecede gerçekleştiremeyen işletmelerin yeminli mali müşavirlerden daha etkin bir destek almaları gerekliliğini de ortaya koymaktadır. Destek alma düzey ortalamaları en yüksek olan faaliyetler, işletme performans ölçüm ve finansal kontrol süreci, bilgi teknolojilerinin kullanılması ve bütçeleme faaliyetleri iken daha az desteğin alındığ1 ve ortalamayı düşüren faaliyetler ise müşteri değeri yaratma analizleri, ürün kalite yönetimi, tedarikçi ve müşteri ilişkileri faaliyetleridir. Ortalamayı düşüren faaliyetlerin geliştirmesine yönelik YMM destekleri yönetim muhasebesi uygulama gücünü artıracaktır. 
Tablo 6. Şirketlerin Yaptıkları Faaliyetler ve YMM’lerden Destek Alma Sıralama Sonuçları (En çoktan en aza doğru sıralanmıştır)

\begin{tabular}{|c|c|c|}
\hline Sira & Şirketlerin Faaliyet Gerçekleştirme Güçleri & Faaliyetlerde YMM'lerden Aldıkları Destekler \\
\hline 1 & Finansal Kontrol & İșletme Performans Ölçümleri \\
\hline 2 & İşletme Performans Ölçümleri & Finansal Kontrol \\
\hline 3 & Bütçeleme & $\begin{array}{c}\text { Yönetim Muhasebesinin Uygulanmasına Yönelik Bilgi } \\
\text { Teknolojilerinin Kullanılması }\end{array}$ \\
\hline 4 & Yatırım Planlamaları & Bütçeleme \\
\hline 5 & $\begin{array}{l}\text { Yönetim Muhasebesinin Uygulanmasına Yönelik Bilgi } \\
\text { Teknolojilerinin Kullanılması }\end{array}$ & Yatırım Planlamaları \\
\hline 6 & Maliyet Kontrolü & Maliyet Kontrolü \\
\hline 7 & Karlılık Analizleri & Karlılık Analizleri \\
\hline 8 & $\begin{array}{c}\text { Etkinlik ve Verimliliğin Tespitine Yönelik Dönemsel } \\
\text { Raporlar ve Değerlendirmeler }\end{array}$ & $\begin{array}{c}\text { Stratejik Kararların Alınmasında İstatistiksel Analizlerin } \\
\text { Yapılması }\end{array}$ \\
\hline 9 & $\begin{array}{c}\text { Stratejik Kararların Alınmasında İstatistiksel Analizlerin } \\
\text { Yapılması }\end{array}$ & $\begin{array}{c}\text { Etkinlik ve Verimliliğin Tespitine Yönelik Dönemsel } \\
\text { Raporlar ve Değerlendirmeler }\end{array}$ \\
\hline 10 & $\begin{array}{c}\text { Ürün ve Hizmet Yaratma Sürecinde Sürekli İyileştirme } \\
\text { Çalışmaları }\end{array}$ & $\begin{array}{c}\text { Ürün ve Hizmet Yaratma Sürecinde Sürekli İyileştirme } \\
\text { Çalışsmaları }\end{array}$ \\
\hline 11 & Ürün Kalite Yönetimi & Müşteri Değeri Yaratma Analizleri \\
\hline 12 & Müşteri Değeri Yaratma Analizleri & Ürün Kalite Yönetimi \\
\hline 13 & Tedarikçi İlişkilerini Geliştirmeye Yönelik Çalışmalar & Tedarikçi İlişkilerini Geliştirmeye Yönelik Çalışmalar \\
\hline 14 & Müșteri İlişkilerini Geliștirmeye Yönelik Çalışmalar & Müşteri İlişkilerini Geliştirmeye Yönelik Çalışmalar \\
\hline
\end{tabular}

Şirketlerin gerçekleştirme gücü en yüksek olan faaliyetleri; finansal kontrol ve işletme performans ölçümleri, yeminli mali müşavirlerden de en fazla destek aldıkları faaliyetlerdir. Buna karşın Ürün, tedarikçi ve müşteri ilişkileri ile ilgili gerçekleştirme güçleri düşük faaliyetler de de yeminli mali müşavirlerden yeterli desteği alamadıkları görülmektedir.

\subsubsection{Yönetim Muhasebesi ile İlişkili Faaliyetlerin Ölçek Ortalamaları Açısından YMM Desteklerinin Analizi}

İlk aşamada her bir faaliyet açısından verilen cevaplar analiz edilmiş ve buna göre yönetim muhasebesinin görevleri doğrultusunda tespit edilen faaliyetlerde yeminli mali müssavirlerin sundukları destekler değerlendirilmiştir. İkinci aşamada ise şirketlerin mevcut durumda yönetim muhasebesi faaliyetleri gerçekleştirme düzey genel ölçek ortalamaları (Ölçek 1) ile YMM’lerden aldıkları destek düzey genel ortalama ölçeği (Ölçek 2) karşılaştırılarak YMM'lerden aldıkları desteklerin etkinliği ölçülecektir. Etkinliğin ölçülmesi amacı ile her iki ölçek sonuçları arasında farkın değerlendirilmesi ve YMM'lerin etkinliğinin tespiti için Wilcoxon Signed Ranks Test uygulanmıştır.

4.3.5.1. Gerçekleştirilen Faaliyetler ve Bu Faaliyetlerin Gerçekleştirilme Derecesinde YMM'lerin Destek Dereceleri Genel Ölçek Ortalamalarının Karşılaştırılması Sonucu YMM'lerin Etkinliğinin Tespiti

Bu süreçte her iki ölçek genel ortalama puanları karşılaştırlacaktır. YMM'lerin etkinliğinin tespiti için karşılaştırma sonucunda beklenen değer YMM'lerin destek derece puanlarının en az işletmelerin hali hazırda uygulama derece puan ortalamaları kadar veya daha yüksek olması durumudur.

Modelde hipotezler şu şekilde belirlenmiştir.

$\mathrm{H}_{0}=$ Şirketlerin faaliyetleri gerçekleştirme gücü ile YMM'lerin etki düzeyi arasında anlamlı bir fark yoktur. YMM'ler mevcut uygulanma düzeyi kadar etki gerçekleştirmektedir.

$\mathrm{H}_{1}=$ Şirketlerin faaliyetleri gerçekleştirme düzeyi ile YMM'lerin etki düzeyi arasında anlamlı bir fark vardır. YMM'ler mevcut yönetim muhasebesi faaliyetlerine yeterli derecede destek sağlayamamaktadır.

$\mathrm{H}_{2}=$ Şirketlerin faaliyetleri gerçekleştirme düzeyi ile YMM'lerin etki düzeyi arasında anlamlı bir fark vardır. YMM'ler şirketlerin mevcut yönetim muhasebesi faaliyetlerine yeterli derecede destek sağlamaktadır. 
İşletmelerin yönetim muhasebesinin görevleri doğrultusunda faaliyetlerin gerçekleştirilme sürecinde, YMM'lerin etkin destek sunma durumunun tespitine yönelik olarak ölçek ortalamalarının normal dağılımı test edilmiştir. Birden çok normallik testi mevcuttur. En çok kullanılan testler içinde Shapiro-Wilks W Test ve Kolmogorov-Smirnov Test uygulanmaktadır (Hair vd., 2010, s. 185). Bu amaçla her iki ölçeğimizin ortalamalarının normallik dağılımı incelendiğinde elde edilen sonuçlar şu şekildedir.

Tablo 7. Normallik Test Sonuçları

\begin{tabular}{c|c|c|c|c|c|c} 
& \multicolumn{5}{c}{ Kolmogorov-Smirnova } & \multicolumn{3}{c}{ Shapiro-Wilk } \\
& Statistic & df & Sig. & Statistic & df & Sig. \\
\hline Ölçek1 &, 141 & 57 &, 007 &, 919 & 57 &, 001 \\
\hline Ölçek 2 &, 230 & 57 &, 000 &, 746 & 57 &, 000 \\
\hline
\end{tabular}

Her iki test sonucuna göre her iki ölçeğin anlamll1k değeri 0,05 'den düşük çıktığ1 için normal dağılmadıkları gözlemlenmiştir. Buna göre parametrik bir test yerine nonparametrik bir test olan Wilcoxon Signed Rank (PASW) Testi uygulanmıstır.

Tablo 8: Wilcoxon Signed Rank (PASW) Test Sonuçları

\begin{tabular}{ccc|c|c}
\hline & & $\mathrm{n}$ & Mean Rank & Sum of Ranks \\
\hline Ölçek 1 & Negative Ranks & $44^{\mathrm{a}}$ & 31,18 & 1372,00 \\
\hline Ölçek 2 & Positive Ranks & $10^{\mathrm{b}}$ & 11,30 & 113,00 \\
\hline & Ties & $3^{\mathrm{c}}$ & & \\
\cline { 1 - 3 } & Total & 57 & & \\
\cline { 1 - 2 } & \multicolumn{2}{c}{5} &
\end{tabular}

Ölçek $2<$ Ölçek 1

Ölçek $2>$ Ölçek 1

Ölçek 2 = Ölçek 1

\begin{tabular}{cc}
\hline Z & $-5,423^{\mathrm{b}}$ \\
\hline Asymp. Sig. (2-tailed) &, 000 \\
\hline Wilcoxon Signed Ranks Test
\end{tabular}

Wilcoxon Signed Ranks Test ${ }_{a}$

Elde edilen sonuçlara göre işletmelerin yönetim muhasebesinin görevleri doğrultusunda faaliyetleri gerçekleştirme gücü ortalama puanları ile YMM'lerden aldıkları destek ortalama puanları arasında anlamlı bir fark vardır. (Ölçek 1 ort $=31,18$; Ölçek 2 ort $=11,30 ; z=-5,423, p=0,000$ ).

44 işletmenin yönetim muhasebesini gerçekleştirme güçleri derece ortalamaları, YMM'lerden bu faaliyetlerde destek alma derece ortalamalarından yüksek iken, 10 işletmede bu faaliyetleri geçekleştirme derece ortalamaları, YMM'lerden aldıkları destek ortalamalarından düşüktür. 3 işletmede ise ölçek ortalamalarının eşit olduğu görülmektedir. 44 işletme yönetim muhasebesi ile ilgili faaliyetleri gerçekleştirirken YMM'lerden etkin düzeyde destek alamamakta, 10 işletmenin ise bu faaliyetleri gerçekleştirirken etkin bir düzeyde destek aldığı görülmektedir. 3 işletmede ise yapılan faaliyetlerde YMM'lerin eşit dereceli desteği görülmektedir. Bu 3 işletmede de YMM' lerden alınan destekler mevcut uygulama gücünü artırmadığ için YMM lerin etkinliğinden bahsedilemeyecektir. Bu durumda $\mathrm{H}_{1}$ hipotezi kabul edilmelidir.

\section{Sonuç}

Yönetim muhasebesinin, işletmelerde yönetim sürecinde verilecek kararlara yardımcı bir muhasebe sistemi olarak kullanılması gerektiği inancındayız. Özellikle belirli büyüklükteki işletmelerin karar alma sürecinde yönetim muhasebesinden yararlanmaları rekabet ve teknolojik üstünlük oluşturmaları açısından önem arz etmektedir. İşletmelerde oluşan verilerin gelecek planlamalarında ve karar alma süreçlerinde kullanılabilmesi ve yönetim muhasebesinden yararlanmaları için işletmelerin muhasebe sistemlerinin bilimsel ve modern şekilde düzenlenmesi gerekmektedir. 
Çalış̧mada işletmelerin yönetim muhasebesi ile ilişkili finansal kontrol, işletme performans ölçümleri, bütçeleme ve yatırım planlama faaliyetlerinde gerçekleştirme güçlerinin yüksek olduğu tespit edilmiştir. Buna karşlık işletmeler yönetim muhasebesi ile ilgili bilgi akışını sağlayacak bilgi teknolojilerinin kullanımı yanında diğer yönetim muhasebesi ile ilgili maliyet kontrolü, karlılık analizleri, etkinlik ve verimliliğin tespitine yönelik dönemsel rapor ve değerlendirmeler, istatistiksel analizler, sürekli iyileştirme, ürün kalite yönetimi, müşteri değer yaratma, tedarikçi ve müşteri ilişki geliştirmeye yönelik faaliyetlerde yeterli ve istenilen seviyede uygulama gücüne sahip değildir.

Uygulama gücü düşük faaliyetlerin gerçekleştirilme sürecinde YMM'lerden yeterli derecede destek alınmadığı görülmektedir. Bu durum yeminli mali müşavirlerin, işletmelerde yönetim muhasebesi ile ilişkili işletme faaliyetlerinde verecekleri desteklerin önemini de ortaya koymaktadır.

Mevcut durumda tespit edilen faaliyetleri gerçekleştiren işletmelerin yalnızca \%17,5'inin bu faaliyetleri yapabilme derecelerinde yeminli mali müşavirlerden yeterli desteği alabildiği görülmekte \%82,5’inin ise yeminli mali müşavirlerden yeterli desteği alamadığ1 görülmektedir.

Sistemin işleyişini koordine edecek en üst dereceli profesyonel yetkinliğe sahip olan yeminli mali müşavirler sadece vergisel uygulamalar olarak değil aynı zamanda bilimsel olarak da işletmelere muhasebe bilgi sisteminin uygulanması açısından yeterli desteği vermelidirler. $\mathrm{Bu}$ destek sayesinde işletmelerin kurumsal yapısına entegre bir muhasebe sisteminin varlığına imkan sağlanacaktır. Bununla birlikte yönetim muhasebesinin görevlerinin ortaya çıkaracağı yararları algılayan işletmeler ve muhasebe meslek mensuplarının sayıca artışı muhasebeye ve muhasebe meslek mensuplarına verilen önemi artırarak organizasyon içerisinde değer gören ve yönetime katkı sağlayan birer aktör olmalarına da imkan sağlayacaktır.

\section{Extended Abstract}

Managers are faced with various problems almost every day during the period regarding their business activities and they make and implement decisions to solve these problems. Most of the data underlying the decisions taken are obtained from the accounting information system of the enterprise. Management accounting, which is an indispensable part of the management function, which is defined as the planning, organization, execution and control of business activities; It is one of the biggest assistants of business management in the decision-making phase. Decision making; Since it can be defined as choosing between options to reach a result, management accounting has an important role in making plans for the future by revealing the situation that occurred in the past with numerical data and performing the control function by comparing the planned and actual results. Management accounting is an information system that constitutes the whole of the accounting process carried out by putting business managers in focus, starting from the collection of information as raw data to the stage of making a report according to the need. The management accountant assumes important duties in analyzing the existing information system in the enterprise, developing and using the system in line with the objectives. In a research conducted by Sunarni in 2013, the duties of management accounting; determined as; evaluating business performance, financial cost control, increasing profitability, budgeting, fixed asset investment planning, tactical decisions, productivity/efficiency improvement, increasing customer value, product quality management, product development studies, customer relationship development, and management information technologies. In addition to these tasks, the data obtained from management accounting should be used to direct and develop supplier relations for a production continuity in line with customer demands and needs.

Management accounting has demonstrated change and evolution depending on the periodic needs and the structures of the enterprises. It is seen that management accounting has gone through four important phases until it reaches today's practices: The first phase refers to the pre-1950 and includes cost definitions and financial control studies. While the second phase covers management planning and control in the 1950 s and 1960s, the third phase appears before us, as emerges as the period of having qualified data in the field of accounting with the increase in global competition and the increase in computer use in the 1980s following the global recession and subsequent oil crises in the 1970s. Finally, the fourth phase is the period consisting of that of value creation, technological developments, and organizational innovations after 1995. The change in the activities and processes of businesses has also shaped the change in 
management accounting. In recent years, the use of advanced production technologies, the intensification of global competition and the stagnation in the economies, etc. have diversified and differentiated the information managers need to find solutions to these problems.

Demonstrating the power of management accounting will be possible with the presence of individuals who have perceived the importance of management accounting within the organization and have professional knowledge and experience in this field. However, it is not always possible to have professional managers, especially in sectors that cannot achieve institutional and strategic structuring. In this case, it is necessary to benefit from the actors included in the economic system regarding advanced accounting systems. The most qualified actors with knowledge in management accounting are Certified Public Accountants. Although not directly involved in the management of businesses, certified public accountants, who have the ability and capacity to direct them, have great responsibilities in the planned continuation of the activities, provided that they are inside or outside the business. Certified public accountants are required not only to get rid of the tendency to offer their functions in line with the tax accounting obligation requested by the system, but also to transfer their knowledge to the sector by revealing their obligations to support the strategic decisions of the companies in a way to serve the modern accounting perception.

The aim of this study is to target; determine the degree to which business managements perform their activities in the decision-making processes in line with the duties of management accounting and the support they receive from certified public accountants in the process of realizing these activities.

In the study, it has been determined that companies have high implementation strength in financial control, business performance measurements, budgeting and investment planning activities related to management accounting. On the other hand, businesses use information technologies to ensure the flow of information about management accounting, as well as other management accounting related cost control, profitability analysis, periodic reports and evaluations for determining efficiency and productivity, statistical analysis, continuous improvement, product quality management, customer value creation, supplier and does not have sufficient and desired level of application power in activities aimed at improving customer relations.

It is observed that sufficient support is not received from CPAs in the process of realizing activities with low implementation strength. This situation also reveals the importance of the support that certified public accountants will provide in business activities related to management accounting in businesses. While it is seen that only $17.5 \%$ of the enterprises that carry out the activities determined in the current situation can get sufficient support from the certified public accountants, it is seen that $77.2 \%$ of them cannot get enough support from the CPAs.

The support of certified public accountants should be increased in order to increase business performances and to ensure that management accounting activities are sufficiently effective in these performances. Thanks to this support, it will be possible to have an accounting system integrated into the corporate structure of enterprises. In addition, the increase in the number of businesses and accounting professionals who perceive the benefits of management accounting's duties will increase the importance given to accounting and accounting professionals, and will enable them to become actors that see value in the organization and contribute to the management.

\section{Kaynakça}

Akgüç, Ö. (1994). Finansal Yönetim. 6.Bask1, İstanbul: Avcıl Yayınlar1.

Bamber, L., Broun, K., \& Harrison, T, W. (2008). Managerial Accounting. First Edition, Prentice Hall.

Büyükmirza, K. (2003). Maliyet ve Yönetim Mubasebesi. Ankara: Gazi Kitabevi.

Dávila, M.P.I., Alonso M.L., \& Gámez M.C.R. (2015). Managerial Accounting for Safety Management. The Case of A Spanish Construction Company. Safety science, November 79, 116-125.

Dekker, H.C. (2016). On The Boundaries Between Intrafirm And Interfirm Management Accounting Research". Management Accounting Research, 31, 86-99. 
Dellmann, K., \& Franz, K.P. (1994). Von Der Kostenrechnung Zum Kostenmanagement, In K. Dellmann, P.F. Klaus (Ed.), Neuere Entwicklungen im Kostenmanagement, (pp.15-30) Verlag Paul Haupt, BernStuttgart-Wien.

Demir, V. (2008). Yönetim Muhasebesindeki Değişim ve Değişimi Etkileyen Faktörler, Muhasebe ve Denetime Bakış Dergisi, 8, 26-51.

Devie, Tarigan, J., \& Kunto, Y.S. (2008). Aplication of Accounting Concepts in The Workplace: A Research of Management Accountant in Surabaya, Indonesia. Journal of International Business Research, 7(3), 89 -104.

Edmonds, T., Edmonds, C., \& Bor Y.T. (2000). Fundemental Managerial Accounting Concepts, USA: McGraw-Hill.

Elmacı, O., (2007). Stratejik Yönetim Açısından Yönetim Mubasebesi, Yayın No. 25, Kütahya: Dumlupınar Üniversitesi Yayını.

Ercan, İ., \& Kan, İ. (2004). Ölçeklerde Güvenilirlik ve Geçerlik., Uludağ Üniversitesi Tap Fakültesi Dergisi, 30(3), 211-216.

Ergin, H., \& Elmacı, O. (1999). Maliyet ve Yönetim Muhasebesinde Yeni Açllimlar: Stratejik Yönetim Muhasebesi. Dumlupinar Üniversitesi Sosyal Bilimler Dergisi, 3(3), 17-50.

Ertaş, F.C. (2015), Yönetim Muhasebesi, İstanbul: Beta.

Ertuğrul, İ. (2014). Toplam Kalite Kontrol, Bursa: Ekin.

Folan, P., \& Browne, J.A. (2005). Review of Performance Measurement: Towards Performance Management, Computers in Industry, 56, 663-680.

Güçlü, N. (2003). Stratejik Yönetim., Gaz̨i Eğitim Fakültesi Dergisi, 23(2), 61-85.

Hair, J.F., Balck, B., Babin B.J., \& Anderson, R.E. (2010). Multivariate Data Analysis: A Global Perspective, 7th Edition, London: Pearson.

Hanzlick, M. (2015). Management Control System and Cross - Cultural Research : Empirical Evidence On Performance Measurement, Performance Evaluation and Rewards in a Cross - Cultural Comparison, Europa Business School, Berlin, Koln: Eul Verlag.

Hilton, R.W. (2005). Managerial Accounting: Creating Value in a Dynamic Business Environment, 6th Edition, Boston: Mc Graw Hill.

Hilton, R.W., \& Platt, D.E. (2014). Managerial Accounting: Creating Value in a Dynamic Business Environment, 10 th Edition, New York: McGraw-Hill Education.

Horngren, T.C., Foster, G., \& Datar, M.S. (2000). Cost Accounting a Managerial Emphasis. 10th Edition, London: Prentice Hall InternatIonal, Inc.

Kaplan, R.S., \& Anderson S.R. (2007). Time-Driven Activity Based Costing: A Simpler and More Powerful Path to Higher Profits, Boston: Harvard Business Review

Karasar, N. (2012). Bilimsel Arastırma Yöntemi. Ankara: Nobel Yayıncilık.

Karasioğlu, F. (2019). Finansal Mubasebe. Ankara: Nobel.

Lazol, I. (2004). Maliyet Mubasebesi, 2.bask1, Bursa: Ekin Yayınlar1.

Li, W. S. (2018). Strategic Management Accounting: A Practical Guidebook with Case Studies, Singapore: Springer Publish.

Magdy, A.K., \& Luther R. (2008), The Impact Of Firm Characteristics On Management Accounting Practices: A UK-Based Empirical Analysis, The British Accounting Review 40, 2-27

Miko L., (1998). Accounting Management Information Used For Strateg1c Decisions, Serbia: Zbornik radova, 22(1), 53-62.

Monden, Y., \& Lee J.Y. (1993). How A Japanese Auto Maker Reduces Costs, Management Accounting, 75, August , 22-26.

Mcwatters, C.S., \& Zimmerman J.L. (2016). Management Accounting in A Dynamic Environment, New York : Routledge.

Nahavandi, S. (2019). Industry 5.0 A Human Centric Solution, Concept Paper, Sustainability, 11, 1-13.

Neely, A., Gregory M., \& Platts K. (1995). Performance Measurement System Design A Literature Review and Research Agenda, International Journal of Operations \& Production Management, 15 (4), 80-116. 
Neely, A. (1999). The Performance Measurement Revolution: Why Now and What Next? International Journal of Operations \& Production Management, 19 (2), 205-228.

Parker, C. (2000). Performance Measurement, Work Study, April 49(2), 63-66.

Prokopenko, J., (2005), Verimlilik Yönetimi Uygulamal El Kitabı. (Çev) Olcay Baykal vd., No:476, Ankara: Milli Prodüktivite Merkezi Yayınları.

Okutmuş, E., Kurar, İ. \& Kahveci A. (2014). Çağdaş Maliyet Yöntemlerinin Ortaya Çıkışına İlişkin Nitel Bir Araştırma, Abant İzzet Baysal Üniversitesi Sosyal Bilimler Enstitüsü Dergisi, 14 (3), 51-77.

Ovunda, A.S. (2015). The Development of Cost and Management Accounting: A Historical Perspective. European, Journal of Humanities and Social Sciences 34(1), 1184-1899.

Rachman, D.J., Mescon M.H., Bovee C.L. , \& Thill J.V. (1996). Business Today, 8. edition, NewYork: McGraw Hill Company.

Sedgley, D.J., \& Jackiw, C. F. (2001). The 123s of ABC in SAP: Using ASP R/3 to Support Activity-Based Costing, New York: Jonh Wiley \& Sons Inc.

Sunarni, C.W. (2013). Management Accounting Practices And The Role Of Management Accountant: Evidence From Manufacturing Companies Throughout Yogyakarta, Indonesia. Review of Integrative Business and Economics Research, 2(2), 616-626.

Yalçın S. (2009). Mamul Tasarım ve Mamul Hayat Seyrinde Maliyetlerin Stratejik Yönetimi. Dumlupınar Üniversitesi Sosyal Bilimler Dergisi, 23, 289-301.

Yıldız, D., \& Uzunsakal, E. (2018). Alan Araştırmalarında Güvenilirlik Tetlerinin Karşılaştırılması ve Tarımsal Veriler üzerinde Bir Uygulama. Uygulamah Sosyal Bilimler Dergisi, 2(1), 14-28.

Yükçü, S., \& Doğanöz, L. (1994). Kalite Maliyetlerinin Muhasebe Sistemi İçindeki Yeri, Standart Ekonomik ve Teknik Dergisi, 33(395), 64-72. 